\title{
Deinococcus aerolatus sp. nov. and Deinococcus aerophilus sp. nov., isolated from air samples
}

\author{
Seung-Hee Yoo, Hang-Yeon Weon, Soo-Jin Kim, Yi-Seul Kim, \\ Byung-Yong Kim and Soon-Wo Kwon
}

Correspondence

Soon-Wo Kwon

swkwon@rda.go.kr
At the time of writing, the genus Deinococcus comprised 36 species with validly published names, isolated from various environments such as soils, hot springs, food, faeces, airborne dust, alpine environments, activated sludge, freshwater and the rhizosphere. Members of the genus are non-spore-forming, non-motile, coccoid or rod-shaped cells and are bright red, orange or pink in colour. With a few exceptions (Callegan et al., 2008; Peng et al., 2009), the majority of the members of the genus Deinococcus are characterized by extreme resistance to UV and gamma radiation and to desiccation.

During a study of bacterial populations in air samples, two pink-coloured bacterial strains were isolated. The air samples were collected outdoors in the Taean region, Korea, using an MAS-100 air sampler (Merck; single-stage multiple-hole impactor). The sampler contained Petri

The GenBank/EMBL/DDBJ accession numbers for the 16S rRNA gene sequences of strains $5516 \mathrm{~T}-9^{\top}$ and $5516 \mathrm{~T}-11^{\top}$ are EU622978 and EU622979, respectively.

Photographs of the TLC plates used for polar lipid analysis and an additional phylogenetic tree constructed using the maximum-parsimony algorithm are available as supplementary figures with the online version of this paper. dishes containing R2A agar (BBL) amended with $0.02 \%$ cycloheximide (Sigma). The air samples were collected directly onto the Petri dishes. After sampling, the plates were incubated at $30{ }^{\circ} \mathrm{C}$ for 5 days and strains $5516 \mathrm{~T}-9^{\mathrm{T}}$ and $5516 \mathrm{~T}-11^{\mathrm{T}}$ were recovered. Routine cultivation was conducted at $28{ }^{\circ} \mathrm{C}$ with R2A media. For comparisons Deinococcus frigens DSM $12807^{\mathrm{T}}$, Deinococcus marmoris DSM $12784^{\mathrm{T}}$, Deinococcus radiopugnans DSM $12027^{\mathrm{T}}$ and Deinococcus saxicola DSM $15974^{\mathrm{T}}$ were obtained from the Deutsche Sammlung von Mikroorganismen und Zellkulturen (DSMZ; Braunschweig, Germany).

Phenotypic characteristics such as Gram staining, catalase and oxidase activities and the hydrolysis of carboxymethylcellulose, casein, chitin from crab shells, DNA, pectin, tyrosine, Tween 80 and starch were performed using the methods of Smibert \& Krieg (1994). The $\mathrm{pH}$ range for growth ( $\mathrm{pH} 4.0-10.0$ at intervals of $1.0 \mathrm{pH}$ unit) was determined in R2A broth which was adjusted with citratephosphate buffer or Tris/ $\mathrm{HCl}$ buffer (Breznak \& Costilow, 1994). Growth at $0,1,2,3$ and $5 \% \mathrm{NaCl}(\mathrm{w} / \mathrm{v})$ was investigated in R2A broth. Growth at various temperatures $\left(5-50{ }^{\circ} \mathrm{C}\right)$ was measured on R2A agar medium. Growth under anaerobic conditions was tested in GasPak jars 
(BBL) at $30{ }^{\circ} \mathrm{C}$ for 15 days. UV irradiation of the cultures was carried out according to the methods of Hirsch et al. (2004) and Weon et al. (2007). Cell morphology and motility were observed under a phase-contrast microscope (Axio; Zeiss) and a transmission electron microscope (912AB; Leo) after cultivation of strains on R2A at $30{ }^{\circ} \mathrm{C}$. Physiological and biochemical properties were further determined with API ZYM, API 20NE and API ID32 GN kits (bioMérieux). Tests in the commercial systems were generally performed according to the manufacturer's instructions. The API ZYM test strip was read after $4 \mathrm{~h}$ incubation at $37{ }^{\circ} \mathrm{C}$ and other API test strips were examined after 5 days at $30{ }^{\circ} \mathrm{C}$.

Fatty acid methyl esters were extracted and prepared by the standard protocol of the Microbial Identification System (MIDI; Microbial ID) after cells had been grown on R2A medium. Isoprenoid quinones were extracted from lyophilized cells and analysed by HPLC as described previously (Groth et al., 1996). The determination of DNA G+C content was performed as described by Mesbah et al. (1989) using a reverse-phase column (Supelcosil LC-18 S; Supelco).
The 16S rRNA gene sequence was determined as described previously (Kwon et al., 2003). The nearly complete 16S rRNA gene sequences of strains $5516 \mathrm{~T}-9^{\mathrm{T}}(1394$ nucleotides) and $5516 \mathrm{~T}-11^{\mathrm{T}}(1430$ nucleotides $)$ were obtained. The identification of phylogenetic neighbours and the calculation of pairwise $16 \mathrm{~S}$ rRNA gene sequence similarities were performed using the EzTaxon server (http://www. eztaxon.org/; Chun et al., 2007). The MEGA (Molecular Evolutionary Genetics Analysis) version 3.1 software package (Kumar et al., 2004) was used for phylogenetic tree construction. Phylogenetic trees were inferred from the neighbour-joining (Saitou \& Nei, 1987), and maximumparsimony (Fitch, 1971) methods. The stability of relationships was assessed by performing bootstrap analyses based on 1000 resamplings.

Strains $5516 \mathrm{~T}-9^{\mathrm{T}}$ and $5516 \mathrm{~T}-11^{\mathrm{T}}$ could be differentiated from each other on the basis of enzymic activities such as valine arylamidase, cystine arylamidase and $N$-acetyl- $\beta$ glucosaminidase. Both strains were clearly separable from $D$. frigens, $D$. marmoris, $D$. radiopugnans and $D$. saxicola on the basis of a variety of characteristics such as growth

Table 1. Differential phenotypic characteristics of strains $5516 \mathrm{~T}-9^{\top}$ and $5516 \mathrm{~T}-11^{\top}$ and closely related species of the genus Deinococcus

Strains: $1,5516 \mathrm{~T}-9^{\mathrm{T}} ; 2,5516 \mathrm{~T}-11^{\mathrm{T}} ; 3$, D. frigens DSM $12807^{\mathrm{T}} ; 4$, D. marmoris DSM $12784^{\mathrm{T}} ; 5$, D. radiopugnans DSM $12027^{\mathrm{T}} ; 6$, Deinococcus saxicola DSM $15974^{\mathrm{T}}$. Data for the reference strains are from Hirsch et al. (2004) and this study. All strains are coccus-shaped and are positive in tests for $\beta$ galactosidase, alkaline phosphatase, esterase (C4), esterase lipase (C8), acid phosphatase, naphthol-AS-BI-phosphohydrolase and $\alpha$-glucosidase. All strains are negative in tests for indole production, glucose fermentation, arginine dihydrolase, urease, lipase (C14), trypsin, $\alpha$-galactosidase, $\beta$ glucuronidase, $\alpha$-mannosidase and $\alpha$-fucosidase. + , Positive; $(+)$, weakly positive; - , negative; A, aerobic; FA, facultative anaerobic.

\begin{tabular}{|c|c|c|c|c|c|c|}
\hline Characteristic & 1 & 2 & 3 & 4 & 5 & 6 \\
\hline Isolation source & Air sample & Air sample & Antarctic soil & Antarctic marble & Irradiated haddock & Antarctic sandstone \\
\hline Colony colour & Pink & Pink & $\begin{array}{l}\text { Pink, salmon to } \\
\text { orange }\end{array}$ & $\begin{array}{c}\text { Pink, salmon to } \\
\text { orange }\end{array}$ & Orange to red & $\begin{array}{c}\text { Pink, salmon to } \\
\text { orange }\end{array}$ \\
\hline Oxygen requirement & A & A & A, FA & A & $\mathrm{A}, \mathrm{FA}$ & $\mathrm{A}$ \\
\hline Oxidase & - & - & $(+)$ & + & $\mathrm{ND}$ & + \\
\hline $\begin{array}{l}\text { Temperature range for growth } \\
\left({ }^{\circ} \mathrm{C}\right)\end{array}$ & $5-40$ & $5-45$ & $1-21$ & $<4-25$ & $<30-41$ & $4-<37$ \\
\hline Optimum temperature $\left({ }^{\circ} \mathrm{C}\right)$ & 30 & 30 & $16-18$ & $9-16$ & 30 & 9 \\
\hline Size $(\mu \mathrm{m})$ & $1.2-1.7$ & $1.4-2.0$ & $0.9-2.0$ & $1.0-4.5$ & $1.0-2.0$ & $2.0-4.0$ \\
\hline $\mathrm{NaCl}$ & $0-1$ & $0-1$ & $0-10$ & $0-<2$ & $0-1$ & $0-1$ \\
\hline Nitrate reduction* & - & - & - & - & + & - \\
\hline Aesculin hydrolysis ${ }^{\star}$ & + & + & - & + & + & + \\
\hline Gelatin hydrolysis* & + & + & - & + & + & + \\
\hline \multicolumn{7}{|l|}{ Enzymic activities ${ }^{\star}$} \\
\hline Leucine arylamidase & + & $(+)$ & + & $(+)$ & + & - \\
\hline Valine arylamidase & + & - & - & - & - & - \\
\hline Cystine arylamidase & + & - & - & - & - & - \\
\hline$\alpha$-Chymotrypsin & $(+)$ & + & - & + & + & + \\
\hline$\beta$-Glucosidase & $(+)$ & $(+)$ & - & - & + & + \\
\hline$N$-Acetyl- $\beta$-glucosaminidase & + & - & - & - & + & - \\
\hline DNA G $+C$ content $(\mathrm{mol} \%)$ & 61.0 & 59.3 & $61.8-65.5$ & 62.8 & 70 & 59.4 \\
\hline
\end{tabular}

${ }^{*}$ Nitrate reduction, aesculin hydrolysis, gelatin hydrolysis and enzymic activities were obtained from the present study using API 20NE and API ZYM test strips. 
temperature, oxidase and other enzymic activities. Strains 5516T $-9^{\mathrm{T}}$ and $5516 \mathrm{~T}-11^{\mathrm{T}}$ were resistant to UV radiation $(254 \mathrm{~nm}, 10 \mathrm{~cm}, 10 \mathrm{~min})$. Escherichia coli ATCC 35607 and Bacillus subtilis ATCC 465 were used as controls and were found to be sensitive. Table 1 shows the main phenotypic differences between strains 5516T- $9^{\mathrm{T}}$, 5516T-11 ${ }^{\mathrm{T}}$ and closely related species of the genus Deinococcus.

Strain 5516T- $9^{\mathrm{T}}$ contained summed feature 3 (iso- $\mathrm{C}_{15: 0}$ $2-\mathrm{OH}$ and/or $\left.\mathrm{C}_{16: 1} \omega 7 c ; 32.9 \%\right), \mathrm{C}_{16: 0}(19.2 \%)$ and iso$\mathrm{C}_{17: 1} \omega 9 c(12.7 \%)$. Strain $5516 \mathrm{~T}-11^{\mathrm{T}}$ contained summed feature $3 \quad(25.1 \%)$, iso- $\mathrm{C}_{17: 1} \omega 9 c \quad(14.4 \%), \mathrm{C}_{17: 1} \omega 8 c$ $(10.7 \%)$ and $\mathrm{C}_{15: 1} \omega 6 c(10.5 \%)$ as the major fatty acids $(>10 \%)$ (Table 2). Strain $5516 \mathrm{~T}-11^{\mathrm{T}}$ could be differentiated from strain $5516 \mathrm{~T}-9^{\mathrm{T}}$ by the presence of iso- $\mathrm{C}_{16: 0}$ $(2.6 \%)$, iso- $\mathrm{C}_{16: 1} \mathrm{H}(3.5 \%)$ and $\mathrm{C}_{17: 1} \omega 6 c(2.2 \%)$. Both strains could be separated from the other closely related species on the basis of qualitative and quantitative differences in the compositions of the fatty acids (Table 2). The major respiratory menaquinone of both novel strains was menaquinone 8 . The polar lipid patterns of both strains were similar, comprising one phospholipid and one aminophospholipid as the major components (see Supplementary Fig. S1 in IJSEM Online). These were consistent with those of Deinococcus cellulosilyticus KACC $11606^{\mathrm{T}}$ and Deinococcus deserti DSM $17065^{\mathrm{T}}$ (Weon et al.,

Table 2. Cellular fatty acid compositions of strains $5516 \mathrm{~T}-9^{\top}$ and $5516 \mathrm{~T}-11^{\top}$ and related strains

Strains: $1,5516 \mathrm{~T}-9^{\mathrm{T}} ; 2,5516 \mathrm{~T}-11^{\mathrm{T}} ; 3$, D. frigens DSM $12807^{\mathrm{T}} ; 4, D$. marmoris DSM $12784^{\mathrm{T}} ; 5$, D. radiopugnans DSM $12027^{\mathrm{T}} ; 6, D$. saxicola DSM $15974^{\mathrm{T}}$. Cells for strains $5516 \mathrm{~T}-9^{\mathrm{T}}$ and $5516 \mathrm{~T}-11^{\mathrm{T}}$ and DSM $12027^{\mathrm{T}}$ were harvested after growth on R2A at $30{ }^{\circ} \mathrm{C}$ for 2 days. Cells for DSM $12807^{\mathrm{T}}$, DSM $12784^{\mathrm{T}}$ and DSM $15974^{\mathrm{T}}$ were collected after growth on R2A at $15{ }^{\circ} \mathrm{C}$ for 5 days. Fatty acids representing $<1.0 \%$ have been omitted.

\begin{tabular}{|c|c|c|c|c|c|c|}
\hline Fatty acid & 1 & 2 & 3 & 4 & 5 & 6 \\
\hline iso- $\mathrm{C}_{13: 0}$ & - & - & - & - & 1.0 & - \\
\hline $\mathrm{C}_{14: 0}$ & 1.0 & - & - & 2.8 & 1.2 & - \\
\hline iso- $\mathrm{C}_{15: 0}$ & 6.6 & 4.6 & 2.3 & 1.7 & 15.1 & 1.4 \\
\hline iso- $\mathrm{C}_{15: 1} \mathrm{~F}$ & 1.1 & 1.2 & - & - & 1.8 & - \\
\hline$C_{15: 1} \omega 6 c$ & 5.5 & 10.5 & 9.9 & 23.9 & 6.2 & 18.8 \\
\hline $\mathrm{C}_{15: 1} \omega 8 c$ & 3.2 & 5.8 & 2.0 & 5.4 & 4.2 & 5.9 \\
\hline $\mathrm{C}_{16: 0}$ & 19.2 & 8.5 & 8.7 & 20.4 & 10.6 & 6.4 \\
\hline iso- $\mathrm{C}_{16: 0}$ & - & 2.6 & 2.7 & - & - & - \\
\hline iso- $\mathrm{C}_{16: 1} \mathrm{H}$ & - & 3.5 & 1.7 & - & - & - \\
\hline $\mathrm{C}_{16: 1} \omega 9 c$ & 1.8 & 2.4 & - & - & - & - \\
\hline $\mathrm{C}_{17: 0}$ & 3.8 & 4.2 & 6.1 & 4.5 & 4.9 & 7.3 \\
\hline iso- $\mathrm{C}_{17: 0}$ & 5.0 & 4.0 & 2.6 & - & 7.3 & 2.0 \\
\hline$C_{17: 1} \omega 6 c$ & - & 2.2 & 5.2 & - & 1.3 & 6.4 \\
\hline $\mathrm{C}_{17: 1} \omega 8 c$ & 5.6 & 10.7 & 13.7 & 2.9 & 7.2 & 18.7 \\
\hline iso- $\mathrm{C}_{17: 1} \omega 9 c$ & 12.7 & 14.4 & 6.7 & - & 21.7 & 8.4 \\
\hline Summed feature $3^{*}$ & 32.9 & 25.1 & 38.5 & 38.6 & 15.8 & 23.7 \\
\hline
\end{tabular}

${ }^{\star}$ Summed feature 3 comprises iso- $\mathrm{C}_{15: 0} 2-\mathrm{OH}$ and/or $\mathrm{C}_{16: 1} \omega 7 c$.
2007). The DNA G $+C$ contents of strains $5516 \mathrm{~T}-9^{\mathrm{T}}$ and $5516 \mathrm{~T}-11^{\mathrm{T}}$ were 61.0 and $59.3 \mathrm{~mol} \%$, respectively.

Strain $5516 \mathrm{~T}-9^{\mathrm{T}}$ exhibited $16 \mathrm{~S}$ rRNA gene sequence similarity levels of $85.6-96.8 \%$ to the type strains of recognized species of the genus Deinococcus. The highest sequence similarities were found with $D$. marmoris DSM $12784^{\mathrm{T}}(96.8 \%)$, D. saxicola DSM $15974^{\mathrm{T}}(96.4 \%), D$. radiopugnans ATCC $19172^{\mathrm{T}}(96.3 \%)$ and $D$. frigens DSM $12807^{\mathrm{T}}(95.0 \%)$. Strain $5516 \mathrm{~T}-11^{\mathrm{T}}$ showed $86.1-94.5 \%$ gene sequence similarity with the type strains of the genus Deinococcus, with the highest sequence similarities to $D$. saxicola DSM $15974^{\mathrm{T}}(94.5 \%)$, D. marmoris DSM $12784^{\mathrm{T}}$ $(94.2 \%)$ and $D$. frigens DSM $12807^{\mathrm{T}}(94.1 \%)$. The sequence similarity between strains 5516T- $9^{\mathrm{T}}$ and 5516T$11^{\mathrm{T}}$ was $94.7 \%$. A Neighbour-joining phylogenetic tree (Fig. 1) showed that strains 5516T-9 ${ }^{\mathrm{T}}$ and $5516 \mathrm{~T}-11^{\mathrm{T}}$ formed one clade with $D$. frigens DSM $12807^{\mathrm{T}}, D$. marmoris DSM $12784^{\mathrm{T}}, D$. radiopugnans ATCC $19172^{\mathrm{T}}$ and $D$. saxicola DSM $15974^{\mathrm{T}}$ with a bootstrap value of $92 \%$. This was also supported by the topology of the maximumparsimony phylogenetic tree with a bootstrap value of $61 \%$ (see Supplementary Fig. S2 in IJSEM Online).

On the basis of the data obtained from this polyphasic taxonomic approach, strains 5516T-9 $9^{\mathrm{T}}$ and 5516T-11 ${ }^{\mathrm{T}}$ represent two novel species of the genus Deinococcus for which the names Deinococcus aerolatus sp. nov. and Deinococcus aerophilus sp. nov. are proposed, respectively.

\section{Description of Deinococcus aerolatus sp. nov.}

Deinococcus aerolatus (ae.ro.la'tus. Gr. n. aer air; L. masc. part. adj. latus carried; N.L. masc. part. adj. aerolatus airborne).

Cells are Gram-positive, non-motile, aerobic cocci (1.2$1.7 \mu \mathrm{m})$. Colonies are pink, convex and circular with entire margins. Growth occurs in the presence of $0-1 \%(\mathrm{w} / \mathrm{v})$ $\mathrm{NaCl}$ (optimum, 0\%), at pH 7-9 (optimum, pH 7) and at 5-40 ${ }^{\circ} \mathrm{C}$ (optimum, $30{ }^{\circ} \mathrm{C}$ ). Catalase-positive and oxidasenegative. Hydrolyses casein, hypoxanthine, Tween 80 and xanthine, but does not hydrolyse chitin, CM-cellulose, DNA, pectin, starch or tyrosine. Positive reactions for aesculin hydrolysis, gelatin hydrolysis and $\beta$-galactosidase. Negative reactions for nitrate reduction, indole production, glucose fermentation, arginine dihydrolase and urease (API 20NE). Assimilates D-glucose, D-mannose, D-mannitol, maltose, potassium gluconate, adipic acid, sucrose, salicin, melibiose, D-sorbitol, valeric acid, potassium 2ketogluconate and L-proline. Weakly assimilates L-serine and L-histidine; does not assimilate L-arabinose, $\mathrm{N}$ acetylglucosamine, capric acid, malic acid, trisodium citrate, phenylacetic acid, L-rhamnose, D-ribose, inositol, itaconic acid, suberic acid, sodium malonate, sodium acetate, lactic acid, L-alanine, potassium 5-ketogluconate, glycogen, 3-hydroxybenzoic acid, L-fucose, propionic acid, 3-hydroxybutyric acid or 4-hydroxybenzoic acid (API 20NE and API ID32 GN). Enzymic activities are shown in Table 1. MK-8 is the predominant isoprenoid quinone. 


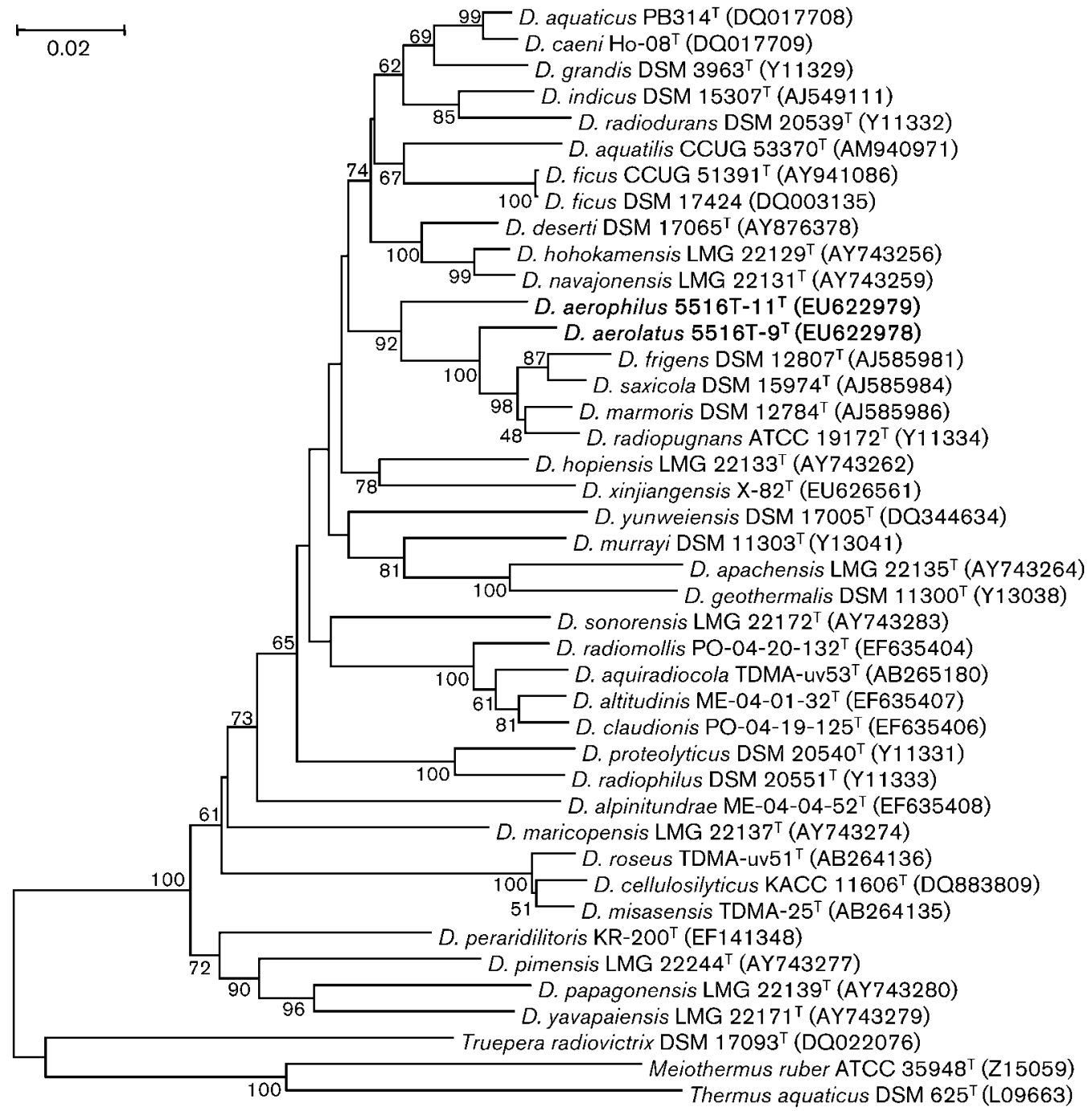

Fig. 1. Neighbour-joining phylogenetic tree, based on $16 \mathrm{~S}$ rRNA gene sequences, showing the positions of strains $5516 \mathrm{~T}-9^{\top}$ and $5516 \mathrm{~T}-11^{\top}$ and species of the genus Deinococcus. Numbers at nodes indicate the percentages of bootstrap support. Bootstrap values $<50 \%$ are not shown. Bar, 0.02 substitutions per nucleotide position.

The polar lipids consist of one phospholipid, several polar lipids and two aminophospholipids. The major fatty acids are summed feature 3 (iso- $\mathrm{C}_{15: 0} 2-\mathrm{OH}$ and/or $\mathrm{C}_{16: 1} \omega 7 c$ ), $\mathrm{C}_{16: 0}$ and iso- $\mathrm{C}_{17: 1} \omega 9 \mathrm{c}$.

The type strain, 5516T $-9^{\mathrm{T}}\left(=\right.$ KACC $\left.12745^{\mathrm{T}}=\mathrm{JCM} 15442^{\mathrm{T}}\right)$, was isolated from an air sample from Taean region, Korea. The $\mathrm{G}+\mathrm{C}$ content of the genomic DNA of the type strain is $61.0 \mathrm{~mol} \%$.

\section{Description of Deinococcus aerophilus sp. nov.}

Deinococcus aerophilus [ae.ro.phi'lus. Gr. n. aer air; N.L. masc. adj. philus (from Gr. masc. adj. philos) loving; N.L. masc. adj. aerophilus air-loving].

Cells are Gram-positive, non-motile, aerobic cocci (1.4$2.0 \mu \mathrm{m}$ ). Colonies are pink, convex and circular with entire margins. Growth occurs in the presence of $0-1 \%(\mathrm{w} / \mathrm{v})$ $\mathrm{NaCl}$ (optimum, $0 \%$ ), at $\mathrm{pH}$ 6-8 (optimum, $\mathrm{pH} \mathrm{7)}$ ) and at $5-45{ }^{\circ} \mathrm{C}$ (optimum, $30{ }^{\circ} \mathrm{C}$ ). Catalase-positive and oxidasenegative. Hydrolyses casein, hypoxanthine and starch, but does not hydrolyse chitin, CM-cellulose, DNA, pectin, Tween 80, tyrosine or xanthine. Positive reactions for aesculin hydrolysis, gelatin hydrolysis and $\beta$-galactosidase. Negative reactions for nitrate reduction, indole production, glucose fermentation, arginine dihydrolase and urease (API 20NE). Assimilates D-glucose, D-mannitol, glycogen, melibiose and D-sorbitol. Weakly assimilates D-mannose, maltose, adipic acid, sucrose, L-serine, valeric acid and L-histidine; does not assimilate L-arabinose, $\mathrm{N}$-acetylglucosamine, potassium gluconate, capric acid, malic acid, trisodium citrate, phenylacetic acid, L-rhamnose, D-ribose, inositol, itaconic acid, suberic acid, sodium malonate, sodium acetate, lactic acid, L-alanine, potassium 5- 
ketogluconate, 3-hydroxybenzoic acid, salicin, L-fucose, propionic acid, potassium 2-ketogluconate, 3-hydroxybutyric acid, 4-hydroxybenzoic acid or L-proline (API 20NE and API ID32 GN). Enzymic activities are shown in Table 1. MK-8 is the predominant lipoquinone. The polar lipids consist of one phospholipid, several polar lipids and one aminophospholipid. The major fatty acids are summed feature 3 (iso- $\mathrm{C}_{15: 0} 2-\mathrm{OH}$ and/or $\mathrm{C}_{16: 1} \omega 7 c$ ), iso- $\mathrm{C}_{17: 1} \omega 9 c$, $\mathrm{C}_{17: 1} \omega 8 c$ and $\mathrm{C}_{15: 1} \omega 6 c$.

The type strain, $5516 \mathrm{~T}-11^{\mathrm{T}} \quad\left(=\mathrm{KACC} \quad 12746^{\mathrm{T}}=\mathrm{JCM}\right.$ $\left.15443^{\mathrm{T}}\right)$, was isolated from an air sample from Taean region, Korea. The $\mathrm{G}+\mathrm{C}$ content of the genomic DNA of the type strain is $59.3 \mathrm{~mol} \%$.

\section{Acknowledgements}

This work was supported by National Academy of Agricultural Science (NAAS), Rural Development Administration, Republic of Korea.

\section{References}

Breznak, J. A. \& Costilow, R. N. (1994). Physicochemical factors in growth. In Methods for General and Molecular Bacteriology, pp. 137154. Edited by P. Gerhardt, R. G. E. Murray, W. A. Wood \& N. R. Krieg. Washington, DC: American Society for Microbiology.

Callegan, R. P., Nobre, M. F., McTernan, P. M., Battista, J. R., NavarroGonzalez, R., McKay, C. P., da Costa, M. S. \& Rainey, F. A. (2008). Description of four novel psychrophilic, ionizing radiation-sensitive Deinococcus species from alpine environments. Int $J$ Syst Evol Microbiol 58, 1252-1258.

Chun, J., Lee, J.-H., Jung, Y., Kim, M., Kim, S., Kim, B. K. \& Lim, Y. W. (2007). EzTaxon: a web-based tool for the identification of prokaryotes based on 16S ribosomal RNA gene sequences. Int J Syst Evol Microbiol 57, 2259-2261.
Fitch, W. M. (1971). Towards defining the course of evolution: minimum change for a specific tree topology. Syst Zool 20, 406-416.

Groth, I., Schumann, P., Weiss, N., Martin, K. \& Rainey, F. A. (1996). Agrococcus jenensis gen. nov., sp. nov., a new genus of actinomycetes with diaminobutyric acid in the cell wall. Int J Syst Bacteriol 46, 234239.

Hirsch, P., Gallikowski, C. A., Siebert, J., Peissl, K., Kroppenstedt, R. M., Schumann, P., Stackebrandt, E. \& Anderson, R. (2004). Deinococcus frigens sp. nov., Deinococcus saxicola sp. nov., and Deinococcus marmoris sp. nov., low temperature and draughttolerating, UV-resistant bacteria from continental Antarctica. Syst Appl Microbiol 27, 636-645.

Kumar, S., Tamura, K. \& Nei, M. (2004). MEGA3: Integrated software for molecular evolutionary genetics analysis and sequence alignment. Brief Bioinform 5, 150-163.

Kwon, S. W., Kim, J. S., Park, I. C., Yoon, S. H., Park, D. H., Lim, C. K. \& Go, S. J. (2003). Pseudomonas koreensis sp. nov., Pseudomonas umsongensis sp. nov. and Pseudomonas jinjuensis sp. nov., novel species from farm soils in Korea. Int J Syst Evol Microbiol 53, 2127.

Mesbah, M., Premachandran, U. \& Whitman, W. B. (1989). Precise measurement of the $\mathrm{G}+\mathrm{C}$ content of deoxyribonucleic acid by highperformance liquid chromatography. Int J Syst Bacteriol 39, 159167.

Peng, F., Zhang, L., Luo, X., Dai, J., An, H., Tang, Y. \& Fang, C. (2009). Deinococcus xinjiangensis sp. nov., isolated from desert soil. Int J Syst Evol Microbiol 59, 709-713.

Saitou, N. \& Nei, M. (1987). The neighbor-joining method: a new method for reconstructing phylogenetic trees. Mol Biol Evol 4, 406425.

Smibert, R. M. \& Krieg, N. R. (1994). Phenotypic characterization. In Methods for General and Molecular Bacteriology, pp. 607-654. Edited by P. Gerhardt, R. G. E. Murray, W. A. Wood \& N. R. Krieg. Washington, DC: American Society for Microbiology.

Weon, H. Y., Kim, B. Y., Schumann, P., Son, J. A., Jang, J., Go, S. J. \& Kwon, S. W. (2007). Deinococcus cellulosilyticus sp. nov., isolated from air. Int J Syst Evol Microbiol 57, 1685-1688. 